\title{
Matizes Políticas e Culturais na criação do Museu Wanderley Pinho (Recôncavo Baiano - I968-I97I)
}

\author{
Mariana Cerqueira Rodriguez \\ Suely Moraes Cerávolo²
}

DOI: |0.265 | 2/museologia.v8i |6.2462 |

\section{Resumo}

O presente artigo trata da criação do Museu Wanderley Pinho (1968-197I), caso específico ao campo museológico na Bahia.A problematização geral versa sobre a centralização da salvaguarda como prática pública pondo em jogo temas mais abrangentes do que a simples conservação física de bens materiais do passado, portanto, em campo político de efeitos sobre o cultural. A materialidade que caracteriza o espaço Engenho/Museu é o fio condutor da análise, pautada em diversas fontes documentais, confluindo a linha teórico-metodológica que advoga as instituições museus como campos discursivos, espaços de interpretação e arenas políticas incidindo sobre as práticas patrimoniais. Observamos as articulações entre instituições, estratégias, agentes, discursos, procedimentos e o nível da ação em condições determinadas. Conclui-se que, a narrativa museográfica trilhou decisões e seleções de modo que o uso do passado manteve a tradição ideológica de um grupo, reunindo, através da figura de José Wanderley de Araújo Pinho, o museu rememorativo de uma camada particular da sociedade baiana.

\section{Palavras-chave:}

Museu do Recôncavo Wanderley Pinho. Patrimônio Cultural. Museu Rural.

\begin{abstract}
This paper evaluates the founding of the Wanderley Pinho Museum (1968-197I), a specific case in the field of museology in the State of Bahia. The critical analysis focuses on the centralization of conservation as a public practice that highlights topics that are wider than the mere physical safeguarding of material items from the past, in which the political effects reign supreme over cultural considerations. The materiality that characterizes the Sugar Mill/Museum space is the element that links the range of aspects evaluated, based on diverse sources of documents, uniting the theoretical-methodological approach that promotes museum-related institutions as places of discourse, interpretive spaces and political arenas impacting heritage preservation policies. We observed the interactions between institutions, strategies, agents, discourses, procedures and the level of action under specific conditions. It was concluded that the museological narrative through specific decisions and choices used the past to maintain the ideological tradition of a group, represented by the figure of José Wanderley de Araújo Pinho, the commemorative museum of a specific stratum of Bahian society.
\end{abstract}

\section{Key words:}

Wanderley Pinho Museum. Cultural Heritage. Rural Museum.

I Mestre em História (Universidade Federal de São Paulo); Museóloga pela UFBA. Bolsista PIBIC/UFBA (2017)

2 Docente do Curso Museologia, PPG Museu; PPG História FFCH/UFBA; Líder do GP Observatório da Museologia na Bahia (CNPq). 


\section{Problematização}

A passagem de uma edificação para museu torna-se matéria para discussões no campo da Museologia e do Patrimônio. $O$ presente artigo trata de um caso específico atinente ao campo museológico na Bahia, envolvendo a problematização geral sobre a centralização da salvaguarda como prática pública onde estão em jogo temas muito mais abrangentes que a simples conservação física de bens materiais do passado, portanto, em campo político de efeitos sobre o cultural.

A criação do Museu Wanderley Pinho (1968; inaugurado em 1971; daqui em diante MWP), no anterior Engenho Freguesia, tombado ainda em 1944 pelo Serviço do Patrimônio Histórico e Artístico Nacional (Sphan), teve a finalidade de preservar a história não só daquele engenho, mas, também, do Recôncavo Baiano, segundo o Instituto do Patrimônio Artístico e Cultural da Bahia (IPAC, 20II, p.5). A materialidade que caracteriza o espaço Engenho/Museu é o fio condutor da análise, pois, não se dá espontaneamente ao tempo em que várias edificações como essas simplesmente despareceram, ruíram ou foram intencionalmente destruídas ao longo de nossa história sem deixar qualquer rastro. Considera-se, para tal aproximação, a confluência da linha teórico-metodológica que vê as instituições museus como campos discursivos, espaços de interpretação e arenas políticas (CHAGAS, 2009; MENESES, 2009) incidindo sobre as práticas patrimoniais, o que permite captar os elos entre instituições envolvidas, as estratégias, os agentes, os discursos, os procedimentos e o processo no nível da ação, que, no caso em tela, foi acionado em condições determinadas. Para descrever a transformação do Engenho Freguesia em museu foi necessário considerar aspectos afetos a políticas, práticas e intencionalidades compondo o espectro da preservação. Além disso, diante da necessidade de apreendê-lo em contexto específico ressalta-se que, no momento da constituição e tentativa de consolidação, o Brasil estava sob governo militar, autoritário e não democráti$\mathrm{Co}^{3}$, que influenciou algumas das principais diretrizes políticas implementadas pelo Governo do Estado da Bahia, durante a gestão de Luís Viana Filho.

A análise das fontes ${ }^{4}$ visou 0 mapeamento dos diversos aspectos que conformaram o contexto de criação do MWP apontando para as transformações funcionais e simbólicas que aquela materialidade vivenciou. Em cada conjunto documental, procuramos reunir e confrontar as informações que traduzissem as estratégias utilizadas para a elaboração e inserção do Museu como parte de uma ideia de patrimônio cultural baiano. Apesar das falhas e ausências da documentação foi possível desenhar o esboço da dinâmica que o configurou levantando algumas hipóteses, a exemplo do princípio gerador da musealização do Engenho ou, em outras palavras, os objetivos, identificando os sinais de con-

3 Estudar o período coloca aos pesquisadores problemas para o acesso às fontes produzidas. Em Salvador, também encontramos dificuldades por diferentes motivos, talvez porque a documentação realmente não mais existe; inacessíveis por falta de tratamento documental adequado; destruídas pela ação do tempo; arquivamento em instituições fora do Estado (Rio de Janeiro, São Paulo e Brasília).

4 Apesar das dificuldades citadas consultamos um grande número de documentos em instituições da cidade de Salvador, cita-se: Arquivo Público do Estado da Bahia (Arquivos Pessoais - Fundo Wanderley Pinho); edições do Jornal da Bahia (1970 e 197I) e na biblioteca as leis e decretos do governo Luís Viana Filho. Não foi possível encontrar o material referente ao ano de 1968; A Tarde (1967, 1968, 1971); Instituto Geográfico e Histórico da Bahia; Arquivo Histórico Municipal; Instituto do Patrimônio Histórico e Artístico Nacional (IPHAN - regional de Salvador); Instituto do Patrimônio Artístico e Cultural (IPAC) e na Diretoria de Museus (DIIMUS); Arquivo do Museu de Arte da Bahia (MAB); Bibliotecas da UFBA (Faculdade de Arquitetura, da Faculdade de Filosofia e Ciências Humanas e na Biblioteca Reitor Macedo Costa - Biblioteca Central UFBA); Biblioteca Pública do Estado da Bahia. 
sagração instituídos nesse processo e alguns procedimentos fomentados pelos agentes que participaram do processo.

Para apresentar e analisar os matizes que compuseram a trajetória do MWP, circundada por interesses políticos associados aos culturais, iniciamos com breve biografia do Engenho Freguesia procurando definir o objeto de análise. Tendo em vista, que os estudos de cultura material remetem às reflexões sobre a presença do indivíduo nos registros materiais (MENESES, 1998), a figura de José Wanderley de Araújo Pinho importa para a compreensão da musealização do Engenho, não só por dar nome ao Museu, mas, pelo lugar social que ocupou e a rede relações estabelecidas no contexto baiano e nacional. Seguimos com o contexto histórico, político e social compreendido entre 1967 e 1971, como dito, caracterizado pela gestão de Luís Viana Filho a frente do Governo do Estado da Bahia, evidenciando relações entre o desenvolvimento regional a partir da industrialização deflagrada no período e as diretrizes do governo federal. Finalizamos e concluímos com aspectos sobre o acervo do Museu, comentando a construção expográfica fonte reveladora da proposta que associa à dimensão ideológica (portanto, política) à narrativa sobre a história de uma Bahia de fausto do passado.

\section{O Engenho Freguesia: a trajetória. $O$ tombamento}

Apesar do longo período de existência, a compreensão do Engenho Freguesia como patrimônio deve ser delimitada a um momento específico que reuniu elementos necessários para operar a transformação de caráter jurídico e simbólica. $O$ tombamento ocorreu ainda durante o Estado Novo beneficiado pela estrutura avalizada por Getúlio Vargas na área da Cultura, e da legislação patrimonial, amparadas pelo Serviço do Patrimônio Cultural Artístico Nacional (SPHAN), partícipe ativo do trabalho de construção da nação. Nas décadas de quarenta consolidava-se o pensamento acerca do patrimônio histórico e artístico brasileiro sustentado na crença comum da universalidade da cultura e da arte, como base da inserção do Brasil no mundo civilizado. Momento em que a arquitetura colonial foi tomada como representativa de uma produção autenticamente nacional, inspirada em muito pelos modernistas e a tendência de "barroquização" (CHUVA, 2003, p.329). O tombamento, instrumento jurídico ${ }^{5}$, foi utilizado como o principal, senão o único meio de consagração do valor cultural de um bem implicando, paralela e fortemente, em questões econômicas e sociais de efeitos simbólicos.

O próprio instituto do tombamento teria contribuído para que a arquitetura fosse alçada à condição de substrato técnico e teórico da política patrimonial, uma vez que o registro no Livro do Tombo pressupunha, ao mesmo tempo, a materialidade indiscutível e a imutabilidade garantida por força da própria limitação ao direito de uso da propriedade (RODRIGUES, 20 I 2, p. I I 3) Essa mentalidade está por trás do tombamento do Engenho Freguesia e sustentará, conforme veremos, as bases do processo de musealização do local trinta anos depois. Para que o Engenho passasse a Museu, outro olhar sobre essa materialidade passa a ser projetado para que cumpra uma nova função social, sem perder de vista a condição de patrimônio nacional e os valores culturais presentes no tombamento com justificativas seletivamente mobilizadas de tal modo que ajam ideias, crenças, afetos, significados, expectativas (MENESES, 2009, p. 32).

5 No Brasil o tombamento foi regulamentado pelo Decreto lei No. 25/1 937 utilizado por agentes oficiais e grupos sociais (FONSECA, 1997, p. 206). 
Nesse ponto, entra na discussão recente, a questão da funcionalidade dos edifícios tombados.A passagem de um edifício de bem tombado para museu possibilita duplo benefício: o da preservação da própria edificação e os cuidados e conservação dos acervos. Há uma linha tênue, diz Mario Chagas, entre museu e patrimônio, muitas vezes confundindo-se musealização com patrimonialização, pois, os conceitos umbilicalmente vinculados à ideia de preservação e ao sentido de posse, a partir de sua dimensão material, espiritual, econômica e simbólica (CHAGAS, 2009, p. 34; grifo nosso). De todo modo, embora sejam processos distintos, realizados em diferentes contextos políticos, sociais e econômicos, os dois não prescindem de elementos comuns como seleção, escolha, ação política, apagamento, negociações e atribuição de valor. Outro aspecto fundamental é a vinculação ao presente, através da ação de indivíduos estrategicamente posicionados, utilizando-se do passado como instrumento de mobilização que atribui valores aos elementos materiais conforme seus desejos e expectativas. $O$ valor no caso, pouco se altera, apenas é direcionado para novas diretrizes em voga ${ }^{6}$.

Sob perspectiva histórica, os museus podem ser vistos através das práticas necessárias para sua concretização, inseridos na dimensão do Patrimônio Cultural, trazendo a ação dos agentes e o papel das instituições nesse processo e, nesse viés, as práticas museológicas da gestão à conservação e exposição transmitem quer concepções e desejos, quer implicações políticas, sociais, educativas, compondo um conjunto de decisões.

Essas breves considerações teórico-conceituais nos servem para situar os liames que rondaram a passagem do tombamento do Engenho Freguesia, que remonta ao século XVI, encravado no Recôncavo baiano, como mencionado, que foi de substancial importância econômica para o Império português durante o período colonial. Uma das primeiras regiões a ser densamente povoada a partir daquele século, cuja organização territorial dos habitantes efetivou-se em condições ambientais e geográficas favoráveis ao desenvolvimento da atividade agrário-exportadora (cana-de-açúcar), através do trabalho rural, desenvolvido nos engenhos funcionando como aglutinadores de pessoas no entorno.A sociedade que se desenvolveu a partir desse modelo produtivo fundamentou-se na aristocracia local e mentalidade patriarcal, com destaque para a figura do senhor de engenho e do escravo.

Dos inúmeros engenhos ${ }^{7}$ que foram construídos no Recôncavo baiano durante os três primeiros séculos de colonização, poucos restaram intactos.Até o início do século $X X$, a principal perspectiva sobre esses imóveis era o fator econômico com função primordial em plantar, colher e tratar a cana efetivando a produção de açúcar em larga escala. Com o advento das usinas caíram em desuso e já não serviam mais para desempenhar a função para o qual foram arquitetados e construídos, ou seja, perderam sua função original. Os anos que se seguem causam a degradação física. Aqueles que perduraram foram 'salvos' pelo olhar patrimonial, voltado à região no decorrer do século $X X$, dando destaque aos engenhos de açúcar como elementos primordiais na estrutura social da história colonial. Para as instancias patrimoniais, a partir desses remanescentes

6 A patrimonialização intimamente associada ao esforço preservacionista a partir da segunda metade do século $\mathrm{XX}$ gerou uma nova sensibilidade face aos referentes culturais potencialmente patrimonializáveis, em ritmo muito veloz, refletindo um boom memorial ampliando o número de arquivos, centros de documentação, museus, lugares de memória e instituições afins (PEREIRO, 2000, p. 27)

7 Engenho aqui é tomado no sentido de estabelecimento industrial, situado em zona canavieira, destinado a moagem da cana, fabrico do açúcar e de outros produtos derivados e pode caracterizar todo o conjunto relativo à cultura e ao processamento da cana, do plantio, colheita, cozimento do caldo, clarificação ou purga do açúcar e a embalagem 
seria possível compreender as diversas fases da ocupação do território, os aspectos históricos, tecnológicos, econômicos, as relações de trabalho, questões religiosas, de alimentação, assim como valores familiares e sociais.

Segundo a documentação referente ao tombamento produzido pelo Sphan ${ }^{8}$, o Engenho Freguesia foi tombado como Patrimônio atendendo-se a tradição histórica e valor excepcional como obra de arquitetura rural. Isso porque a simples durabilidade do artefato que, em princípio, costuma ultrapassar a vida de seus produtores e usuários originais, já o torna apto a expressar o passado de forma profunda e sensorialmente convincente (MENESES, 1998, p.90). Na mesma linha de pensamento outros processos de tombamento junto ao órgão federal, referentes a engenhos no estado da Bahia, foram concretizados tanto à época como nos anos seguintes.

$\mathrm{Na}$ análise desses bens, convém relevar as complexas relações sociais e espaciais decorrentes da ocupação do território para a produção do açúcar, considerando não só a forma material que cada edifício assumiu ao longo do tempo, mas, igualmente, a disposição relativa ao conjunto e a situação no espaço geográfico e político. Perspectiva que se associa às diretrizes da cultura material tomando o Engenho na condição de documento cogitando-se as relações sociais que o permeiam, relembrando, nesse ponto, que características físicas são resultado de um processo social que atua desde a seleção da matéria-prima, de estilo, da funcionalidade, da economia, variando de acordo com as circunstâncias geográficas, as técnicas possíveis (REDE, 1996).

Alguns aspectos da trajetória do Engenho Freguesia são ressaltados na documentação produzida para as ações patrimoniais, a exemplo da temporalidade (I560), o contexto de sesmaria' , a região do Matoim (lugarejo próximo, atualmente pertence ao Município de Candeias), localização ${ }^{10}$, facilidades do entorno"'.As circunstâncias nas quais foram implantadas a manufatura açucareira têm importância vital para a formação histórica brasileira, consolidando a produção do açúcar para exportação como a principal atividade econômica ao longo dos três primeiros séculos de colonização. Em antigas cartas geográficas Engenho recebeu a denominação de Novo Caboto, Matoim ou até Nossa Senhora da Piedade (ROCHA, 1973, p.6).

O histórico de construção desses engenhos demonstra que não eram isolados. Formavam sistemas complexos, pequenas comunidades, construídos para satisfazer as necessidades não só de residência, mas, acima de tudo para permitir a produção eficiente e rentável de açúcar. Portanto, fundamentalmente, respondiam pela função econômica, o que acabou por influenciar diretamente na maneira de viver, ao mesmo tempo em que precisou ser adaptada às condições possíveis no território brasileiro. Compunham-no: a casa da moenda, casa da fornalha, tendal das forjas e casa de purgar, depois passou abranger o conjunto da propriedade senhorial, as plantações, a casa-grande, a capela e a senzala.

8 SPHAN - SERVIÇO DO PATRIMONIO HISTÓRICO E ARTISTICO NACIONAL. PROCESSO DE TOMBAMENTO 322 T-1943: Engenho Freguesia. Acervo Digital IPHAN. Disponível http://acervodigital. iphan.gov.br/xmlui/discover..Acessol 2.05.2018.

9 Doado ao sesmeiro Sebastião Álvares, depois herdada em 1584 por seu filho Sebastião Faria.

10 O Engenho Freguesia manteve-se em localização estratégica na Baía de Aratu, a 43 km de distância de Salvador, numa grande enseada localizada no nordeste da Baía de Todos os Santos, próximo à entrada do canal de Cotegipe, em frente a ilha de Maré.

II A localização geográfica facilitou amplo acesso a água e energia hidráulica aproveitando a rede fluvial formada pelos rios Paraguaçu, Açu, Subaé e Jaguaribe que deságuam na baía, e pelos rios Pojuca, Jacuípe e Joanes que deságuam diretamente no oceano Atlântico (AZEVEDO, 2009, p.23). O Engenho esteve servido de vias de transporte do açúcar, facilitando a exportação para a Europa (PIRES, 1994). 
Utilizando a tração animal era chamado "trapiche”, e movido a roda de água "engenho real". "Banguês" os engenhos a vapor, na segunda década do século XIX. (AZEVEDO, 2009, pp.19 e 09).

Há relatos que por volta de 1624 os holandeses atacaram e incendiaram o Engenho Freguesia e a igreja matriz de Nossa Senhora da Piedade. Entre 1680 e 1690 o Engenho foi vendido para Antonio da Rocha Pita, permanecendo sobre o poder dessa família por vários anos. A partir do fim do século XVII diversos fatores deslocaram a importância e a efetividade do açúcar como produto econômico para a Coroa Portuguesa. Além da descoberta de ouro e diamante nas Minas Gerais, as políticas protecionistas adotadas pelas metrópoles europeias em favor de suas colônias nas Antilhas prejudicaram imensamente o mercado nacional.

O arranjo espacial das edificações no conjunto dos engenhos não sofreu grandes alterações no decorrer dos três primeiros séculos da colonização, em razão da evolução não significativa da técnica utilizada para a agricultura e a manufatura do açúcar. No decorrer dos anos, a família dilatada, resultante do patriarcalismo poligâmico, acrescida por afilhados, agregados e compadres, gerou programas arquitetônicos extensos e complexos (AZEVEDO, 2009, p.19). Não havia um modelo fixo e foram utilizados todos os sistemas construtivos conhecidos variáveis de acordo com a disponibilidade de materiais e posses do senhor de engenho. Ocorreu certa evolução arquitetônica das casas grandes que inicialmente eram construídas de taipa e de adobe passando para construções mais sólidas de alvenaria, usando tijolos de grande tamanho e peso. Em decorrência da continuidade do uso social, as casas de senhores constituem a grande maioria dos remanescentes arquitetônicos dos engenhos do século XIX na Bahia.Algumas casas-grandes adquiriram porte monumental com tratamento erudito, brasões, pinturas de teto e rico mobiliário.

$\mathrm{Na}$ ocasião do tombamento, o Engenho Freguesia era formado por um grande barracão recoberto por telhado de seis águas, formado por estrutura autônoma constituída por pilares de tijolo chato e esteios de madeira sustentando a cobertura. As paredes de vedação das Casas de Caldeiras e de Purgar em alvenaria mista, pedra e tijolo. Mas nem sempre teve a forma arquitetônica que hoje apresenta. Foi bem mais simples no início.Acredita-se que a conformação atual do conjunto arquitetônico do Engenho, composta por casa-grande e capela anexa ${ }^{12}$, com 55 cômodos além da fábrica aconteceu por volta de 1760, com a reconstrução pelo Capitão Mor Cristovão da Rocha Pita (IPAC, 20I I, p.5). Nesse mesmo período, o Engenho Caboto foi incorporado à Freguesia (IPAC, 1978, p. 32). Com o aumento da produção de açúcar por volta de 1817 , - Engenho foi recuperado e o maquinário substituído (antigas almanjarras por maquinas a vapor). Em 1848,Antonio Bernardino da Rocha Pita e Argolo, futuro Conde de Passé, adquire o engenho e realiza intervenção significativa de restauro do conjunto arquitetônico, segundo o mesmo documento do Iphan, tem-se que, dessa época datam as grades dos calções (substituindo antigos varais de ferro do século XVIII) e as pinturas do brasão de armas no forro de uma das casas das salas da casa-grande.

Expressivas mudanças socioeconômicas aconteceram no território do

12 A Capela Nossa Senhora da Piedade, completa o conjunto cuja data exata de fundação é incerta, possivelmente, por suas características foi construída no fim do século XVIII.A construção se distingue por seus traços arquitetônicos, conjugada ao sobrado, parte da fachada encravada no corpo da casa; um dos raros exemplares ainda conservados. A Capela de Nossa Senhora da Piedade anteriormente denominada Igreja de Nossa Senhora da Conceição da Freguesia, conta com corredores laterais e tribunas, reminiscências do estilo rococó.VER ROCHA, 1973. 
Recôncavo baiano a partir da abolição do tráfico de escravos africanos, impactando mais severamente a estrutura local no fim do século XIX. Pouco a pouco os engenhos perderam a posição de destaque e o papel de unidade centralizadora, destronando, por sua vez, uma parcela da elite senhorial aí existente. Superados pelas usinas, também equipadas com maquinaria importada, moderna e eficiente, instaladas sem participação do governo, os engenhos não tiveram condições de rivalizar com as gigantescas empresas agroindustriais. Alguns foram absorvidos por elas, outros reduzidos à condição de meras fazendas de cana, fornecedoras de matéria-prima (DIAS, 20I5). Em I877 com a morte do Conde de Passé, o Engenho foi doado para as netas Maria Luiza e Antonia Tereza, e administrado pelo pai, João Maurício Mariani Vanderlei, o barão de Cotegipe. Em 1886 através do casamento de Maria Luísa com João Ferreira de Araujo Pinho, - Engenho passa a pertencer à família Araújo Pinho, que o administrará já em processo de decadência até a sua desativação em 1900. Por ser neto do Barão de Cotegipe, José Wanderley de Araújo Pinho herda o Engenho Freguesia, passando a administrá-lo com outros engenhos de propriedade da família.

Os impactos e interações decorrentes do fim da economia açucareira no Recôncavo baiano, seguidos da implantação da indústria foram responsáveis por profundas modificações sociais da região, alterando significativamente não só a organização social como a paisagem. $O$ acelerado processo trouxe a questão patrimonial para a ordem do dia e o discurso para estancar a degradação contínua e progressiva de alguns remanescentes materiais do passado foi amplamente divulgado.

Godofredo Filho, diretor da $5^{\mathrm{a}}$ região do Sphan, solicita, através do ofício $n^{\circ} 43$ endereçado a Rodrigo de Melo Franco de Andrade, o tombamento dos Engenhos Freguesia e Matoim, localizados na mesma região. $\bigcirc$ processo se iniciou em 8 de maio de 1943, para o que foram enviados em anexo notas históricas e descritivas sobre as duas construções e ampla documentação fotográfica dos elementos arquitetônicos. Os testemunhos "da velha vida assucareira naquela parte mais ilustre de nosso recôncavo" deviam receber proteção imediata.Vistos como antiguidade, exemplos das "mais estáveis civilizações assucareiras do continente.”, em condições aceitáveis e feições impressionantes foram tomados como documentos arquitetônicos e testemunhos evocativos de uma sociedade e de uma economia "irremissivelmente perdida[s.]" (SPHAN, 1943, p.2 e 4).

A lista de proprietários revela que o Engenho Matoim era propriedade de Durval Cerqueira Lima e o Engenho Freguesia pertencia ao espólio de Dona Maria Luiz Wanderley de Araújo Pinho, cujos herdeiros eram José Wanderley de Araújo Pinho e Joaquim Wanderley de Araújo Pinho. No dia 9 de junho de 1943, foi emitida a notificação ${ }^{\circ}$ 509, pelo Sphan, direcionada ao Juiz da Vara de Órfãos e Sucessões do Município do Salvador. Enviada por Rodrigo de Melo a solicitação ordenava que se juntasse a notificação aos autos do inventário dos bens deixados por Dona Maria Luiza Wanderley de Araújo Pinho, para que com isso tivessem ciência os demais herdeiros e interessados. Nota-se, pelo documento, que o dispositivo do tombamento altera questões de propriedade:

Tendo este serviço deliberado efetuar o tombamento da antiga casa de residência de Engenho Freguesia, assim como das construções anexas, sitas no distrito de Matoim, município do Salvador, nesse Estado e pertencente ao espólio de D. Maria Luiza Wanderley de Araújo Pinho, para os fins estabelecidos no Decreto-lei No 25 de 30 novembro de 1937, venho solicitar a v. excia. Que queira 
dar ciência da referida deliberação ao inventariante do dito espólio, para que este, no prazo de 15 dias, venha anuir ao tombamento ou impugna-lo, na forma do disposto do art. $9^{\circ}$ do citado decreto-lei. (SPHAN, 1943)

Um papel simples, manuscrito e assinado por Joaquim e José Wanderley de Araújo, dá a concordância de ambos para com o tombamento em 9 de setembro de 1943. Um ano depois, em I4 de setembro de 1944, foi inscrito sob o n 237 no Livro de Tombo número 2, folha 40 e sob o número 304, no livro de tombo $n^{\circ} 3$, em 14 de setembro de $1944^{13}$. Documento manuscrito assinado pela perita em Belas Artes Judith Martins e pelo diretor do SPHAN, Rodrigo de Melo Franco de Andrade.

O processo todo levou um ano para se concretizar. Não houve deliberação em Conselho. $O$ tombamento era um recurso ainda recente, tendo em vista que foi instituído em 1937, embasado pelo ideário preservacionista. Wanderley Pinho pode ter articulado o tombamento do Engenho junto ao Sphan, dada sua influência. No entanto, seu papel é relevante não apenas por ter sido o dono do Engenho, mas por trabalhar em prol da defesa dos bens históricos e arquitetônicos, com estreitas relações junto àquele órgão federal. Com a instalação da sede regional em Salvador, no ano de 1937, Wanderley atuou como colaborador nos estudos para o desenvolvimento de diversos alguns processos de tombamento, como é o caso do Engenho Freguesia (DÓClO, 20l4).

No Brasil, essa prática, foi utilizada por agentes oficiais e grupos sociais como recurso de consagração do valor cultural de um bem.Além de instrumento jurídico, tem implicações econômicas, sociais e opera fortemente no campo simbólico, trazendo a essa prática uma complexidade instigante:"Ter um bem de sua cultura tombado pode significar para grupos, benefícios de ordem material e simbólica, além da demonstração de poder político." (FONSECA, I 997, p. 206).

Com o tombamento, a função social do Engenho foi alterada naquele momento, diferenciando-o dos demais. Assume-se a importância da edificação, uma vez que para a inscrição de um bem de valor cultural no Livro do Tombo importa a existência de uma materialidade inequívoca (visto que insubstituível) sem a qual o tombamento não pode subsistir. $O$ nome atribuído foi: Engenho Freguesia: Sobrado, Fabrica de Açúcar e Capela Nossa Senhora da Piedade. Na época, o prédio não tinha o uso de museu.

\section{Wanderley Pinho: a patrimonialização do Engenho e a rede de socia- bilidade}

A influência de José Wanderley de Araújo Pinho (1890-1967) ${ }^{14}$ no processo de patrimonialização do Engenho Freguesia, e sua atuação na conformação do campo patrimonial que se instituía na década de 30, ainda merece maior investigação, sobretudo nos centros de documentação do Rio de Janeiro que

$13 \mathrm{O}$ processo de tombamento reúne um conjunto de 102 fotos em preto e branco sobre os Engenhos Matoim e Freguesia da primeira metade da década de quarenta, registrando características arquitetônicas das edificações, elementos decorativos, a inserção na paisagem, o estado de conservação e peças de valor artístico ou cultural.

I4 Nascido no ano de 1890 em Santo Amaro (BA) traçou trajetória de destaque na vida política e cultural. Assumiu diversos cargos e posições públicas ao longo dos anos, atuando nas esferas municipal e estatal. Viveu por muito anos no Rio de Janeiro, atuando no âmbito federal. Foi casado com Estela Calmon Du Pin e Almeida, segunda filha do casal Góes Calmon, cujo matrimonio não gerou herdeiros. 
guardam grande parte a respeito do tema ${ }^{15}$. Ele não herdou apenas o Engenho, mas um capital político e econômico consistente de seu berço familiar tanto materno quanto paterno ${ }^{16}$, oriundo das tradicionais aristocracias da região do Recôncavo baiano que, mais tarde, estarão representadas no Museu. No ambiente familiar, recebeu formação exemplar para os padrões da época, como era de se esperar para um herdeiro desse porte. Traçou a trajetória na vida pública com destaque para a atuação como político. Em 1924 foi deputado federal pela Bahia, exercendo um segundo mandato em 1927, e em 29 de agosto de 1930 apresentou ao Congresso Nacional o projeto de lei inovador referente à proteção dos bens culturais, entusiasta que foi da preservação ${ }^{17}$.

Atuando como deputado federal ${ }^{18}$, Wanderley propôs medidas de preservação elaboradas no bojo das discussões que deram origem ou inspiraram a criação de órgãos de preservação patrimonial. Por essa razão, é considerado por alguns teóricos do campo, o grande antecessor da atual lei de proteção ao patrimônio histórico e artístico nacional, pois possuiu o mérito de reunião de boas propostas em volta de uma única lei (TELLES, 2009, p.70).

Ainda na Bahia, Wanderley Pinho teria exercido influência no processo de criação da Inspetoria Estadual de Monumentos Nacionais do Estado da Bahia em 1927 e, na década anterior, em 1917, antes mesmo da criação do Museu do Estado (1918) propôs a criação da Comissão dos Monumentos e das Artes, sob a orientação Instituto Geográfico e Histórico da Bahia, e dentre as tarefas caberia elaborar inventário de bens móveis e imóveis da Bahia (CERÁVOLO, 20I4).

Frequentando o ambiente da intelectualidade da capital baiana,Wanderley Pinho foi amigo de Rodrigo Melo de Franco de Andrade, Diretor Geral do Sphan, com afinidade acerca do interesse de ambos pelos debates em torno da preservação do patrimônio. Em 1947, quando nomeado pelo Governo Constitucional como prefeito da cidade de Salvador, buscou aproximar o Sphan da esfera municipal, inserindo esse órgão nos planos de governo (DÓClO, 20I4). Sua gestão foi marcada pela idealização e execução do Festival Comemorativo do IV Centenário da Fundação da Cidade de Salvador, realizado em 29 de março de 1949 no centro da cidade ${ }^{19}$. O evento teve grande repercussão e gerou, entre outros a Exposição Iconográfica e Bibliográfica Baiana, realizada no Paço do Saldanha. (DÓClO, 20I4, p.98). Além disso, deixou vasta produção bibliográfica

I5 A Coleção de documentos Wanderley Pinho, pertence ao acervo do Museu Histórico Nacional. São 6.000 documentos cartoriais, de Câmaras municipais de diversas cidades da Bahia, documentos avulsos, literários, compreendendo os séculos $\mathrm{XVI}$ ao $\mathrm{XX}$. A coleção está em processamento técnico e será disponibilizada para consulta publica ao fim do processo.

16 A mãe Maria Luísa Wanderley de Araújo Pinho era filha de João Maurício Wanderley, o Barão de Cotegipe.A importância do Barão revela-se na atuação como político durante o período do Império quando deputado (1843-1856), presidente da província da Bahia em (1852), ministro da Marinha (1855 e 1868), senador pela Bahia (1856-1899), ministro da Fazenda (1865), ministro dos Estrangeiros (1869 e I875). O pai João Ferreira de Araújo Pinho foi presidente da província de Sergipe em 1876 e governador da Bahia de 1908 a 1911 .

17 Vice-presidente do Instituto Geográfico e Histórico Brasileiro e membro da Academia de Letras da Bahia. Foi membro do Arquivo Histórico de Salvador, pertenceu ao Instituto Genealógico da Bahia, à Associação Brasileira de Educação, à Sociedade dos Artistas Brasileiros e do Instituto Geográfico e Histórico da Bahia.

18 Wanderley Pinho exerceu durante algum tempo a advocacia atuando em Salvador, Santo Amaro e no Rio de Janeiro, então Capital do país. Ainda na Bahia, tornou-se Promotor Público do município de Mata de São João e da capital Salvador. Foi procurador do Estado da Bahia junto ao Supremo Tribunal Federal (STF) e ministro do Tribunal de Contas.

19 Ver PASSOS, Alan.A cidade de Salvador e os seus 400 anos: Política, História e usos do passado (Bahia, 1949). Dissertação. PPG História, 20 I6. Disponível < https://repositorio.ufba.br/ri/handle/ri/2 I 37. >.Acesso 17.04.2019. 
como historiador ${ }^{20}$. Uma obra em especial destaca-se em sua produção e não por acaso versa sobre o Engenho Freguesia. Dois anos após a concretização do tombamento, em 1946, a publicação do livro História de um Engenho do Recôncavo será um marco referencial para a compreensão não só do Engenho Freguesia, mas de outros exemplares da arquitetura rural do açúcar na mesma região ${ }^{2 !}$.

Não obstante a relevância patrimonial do Engenho Freguesia e importância social de Wanderley Pinho para a Bahia foi necessário que, uma série de sujeitos estrategicamente posicionados mobilizassem forças e agissem no intuito de levar a cabo um projeto que contemplasse a sua memória. Após sua morte (I967), a viúva Stela Calmon informa o Governo do Estado sobre o interesse em desapropriar o Engenho Freguesia, para sede de um futuro Museu do Recôncavo Wanderley Pinho, com a finalidade de preservar a história do Engenho e a do Recôncavo Baiano. A venda do Engenho para sediar um museu que levasse o nome de seu marido, também parecia um bom destino para a propriedade rural.É de se supor que sendo uma Calmon, Stella sabia muito bem do valor que teria para a possível imortalização do finado marido. Sua participação não passou despercebida: era a testemunha viva, a companheira, a colaboradora desde 1921 que lia e revia os trabalhos, "guardando grande veneração pela sua memória.” (NASCIMENTO, 1987, p.23I).A criação de um museu com seu nome foi apenas uma dentre a série de estratégias (conscientes ou não) no intuito de preservar o seu legado, incluso a doação dos arquivos pessoais ${ }^{22}$.

As relações estabelecidas entre Wanderley Pinho e os diferentes sujeitos ocupantes de cargos e posições privilegiados, sobretudo no campo intelectual e político, facilitou a mudança essencialmente simbólica alimentada por homenagens. Luís Viana Filho, então Governador da Bahia (I967-I97I) envolveu-se pessoalmente para agir em prol do projeto. Amigo pessoal de Wanderley Pinho, com similar trajetória de vida $^{23}$, ambos conquistaram destaque no campo inte-

20 Foi professor catedrático de História do Brasil na Faculdade de Filosofia da Universidade Federal da Bahia, produzindo pesquisas, estudos e livros a exemplo de Política e políticos do Império (1930), Cotegipe e seu tempo (1937), Dom Marcos Teixeira, quinto bispo do Brasil (1940), Salões e damas no Segundo Reinado (1942) entre outros. Em homenagem póstuma, comemorando o centenário de seu nascimento, Luiz Viana Filho, o governador responsável pela criação do Museu, discursou longamente sobre algumas das habilidades do amigo (VIANNA FILHO, 1990).

2I A motivação para o denso e detalhado trabalho adveio de concurso de monografias promovido pelo Instituto do Açúcar e do Álcool, com o objetivo de estimular e premiar o esforço da pesquisa histórica, da investigação original nas fontes da nossa história econômica e social, no setor da indústria açucareira. O texto deveria versar sobre um engenho de mais de 200 anos, contemplando aspectos de fundação, histórico familiar dos proprietários, limites, transformações, levantamento topográfico, regime de trabalho, lavouras, produção. O Engenho Freguesia adequava-se perfeitamente ao tema proposto, além de contar com um diferencial de seu proprietário ser historiador e possuir relação afetiva e familiar com o espaço. Para essa obra Wanderley usou vasta documentação para reconstruir a história do Engenho Freguesia oportunidade para escrever sobre a história de sua própria família (ROCHA, 1973, p.8).

22 No Rio de Janeiro, cidade em que viviam, Stella doou grande parte da documentação pessoal do marido. Cerca de 80 latas de documento e 20 latas de iconografia, referente a grande parte da produção intelectual, entre artigos, notas, fichas de pesquisa, textos, discursos e minutas proferidos por Wanderley Pinho durante sua carreira pública ao Instituto Histórico e Geográfico Brasileiro (IHGB). Uma coleção de documentos reunidos por Wanderley Pinho está preservada no Arquivo Histórico do Museu Histórico Nacional do RJ, e na Bahia, o Arquivo Municipal de Salvador recebeu em 1968 a doação de 43 pacotes alusivos ao período em que foi prefeito (1945-1949) No fim dos anos sessenta documentos se encontravam no Palacete Subaé, em Santo Amaro da Purificação (7.407 documentos referentes a grande parte de sua atuação na vida pública nacional).

23 Formação em Direito; professores no curso de História na Faculdade de Filosofia e Ciências Humanas da Universidade Federal da Bahia; ocupantes da mesma cadeira de História do Brasil (CUNHA, 1973, p.3I); integrantes do mesmo partido político baiano (Concentração Autonomista (Partido político baiano fundado em 2 de julho de 1935. Foi extinto junto com os demais partidos políticos do país pelo Decreto $\mathrm{n}^{\circ} 37$, de 2 de dezembro de 1937) 
lectual em Salvador e no Rio de Janeiro, com significativa produção bibliográfica e biografias de personalidades políticas e literárias do Brasil que agradavam os sócios dos institutos e academias das quais eram membros. Em conferência na solenidade que celebrou o Centenário de Wanderley Pinho, pronunciada em 19 de março de 1990, na Reitoria da Universidade Federal da Bahia (TELLES, 2009), Luís Viana ressalta, em sua fala carregada de sentimentalismo, os valores morais do amigo e a capacidade intelectual sublinhando a erudição do amigo em História de um Engenho do Recôncavo (VIANA FILHO, 1990, pp. 5 e II I) ${ }^{24}$.

Trinta anos depois do decreto de abertura do Museu, em 1998, a Secretaria da Cultura e Turismo e a Fundação Cultural do Estado da Bahia, patrocinam a publicação do Inventário Sumário do acervo José Wanderley de Araújo Pinho, com o objetivo de tornar mais acessível o acesso as fontes sobre sua vida e obra.A apresentação pela diretora do Museu, Marinaide Linhares Ribeiro Santana enaltece o Museu pela guarda da "história dos homens ao longo da formação do Brasil e da história de vida de um homem que, sem dúvida, figurou no cenário baiano como exemplo de luta e amor à sua terra."(BAHIA. Secretaria ..., 1998, p.3).

O contexto de criação do Museu do Recôncavo Wanderley Pinho se dá entre 1967, momento de sua morte e 1971 data de sua efetiva inauguração pelo então governador Luís Viana Filho. $O$ ano de 1964 marca o momento em que as Forças Armadas assumem o poder político e estabelecem amplamente os limites da ação civil no Brasil, controlando o aparato jurídico, legislativo e executivo. À época, o conceito de integridade nacional também dependeu de determinada memória nacional a preservar como instrumento de desenvolvimento (ORTIZ, 1991). Estava colocado o problema de como integrar as diferenças regionais no interior de uma hegemonia estatal. A noção de integração servira de premissa para a elaboração de políticas que objetivavam coordenar as diferenças sob a justificativa do mesmo objetivo nacional. Nesse momento, o Estado concebeu uma política cultural voltada para o mercado, incentivando a exploração comercial da cultura através do turismo, causando um impacto importante no processo de mercantilizarão da cultura popular, das atividades folclóricas e do artesanato (SANTOS, 2016). Segundo Ortiz (199I) a presença do estado autoritário se deu, sobretudo, através da normatização e do estímulo à esfera cultural desde que partisse de ações sistêmicas e centralizadas. Observou-se um estímulo à cultura com a criação de instituições específicas para tratar do tema Patrimônio e Museus, além da normatização do campo, a partir de leis decretos, portarias e a criação de instituições específicas para esse fim.

No campo do Patrimônio Artístico e Cultural Nacional, o período caracteriza-se pela gestão de Renato Soeiro, a frente do principal órgão de preservação: o Sphan. Assumindo a presidência na ocasião da aposentadoria de Rodrigo M. F. de Andrade, cargo que ocupou de 1967 a 1979, deu continuidade de certa forma às políticas que vinham sendo aplicadas. Soeiro elaborou o Plano Estratégico de Ação que seria posteriormente institucionalizado com os Compromissos de Brasília (1970) e o Compromisso de Salvador (197I) tratando da descentralização do órgão e criação de uma rede de preservação do patrimônio nacional, integrada pela Dphan (anterior Sphan ${ }^{25}$ ) e instituições assemelhadas estaduais

24 A historiadora Consuelo Pondé de Sena, presidente do IGHB, aluna, discípula e amiga enquanto cursava as disciplinas de História do Brasil e da Bahia no curso de Geografia e História, da UFBA, organizou textos históricos de José deWanderley de Araújo Pinho (Coletâneas de textos históricos. Bahia:Artes Gráficas, ano 1990, 30/ 4/ 1991).

25 Na gestão de Renato Soeiro se deu a articulação junto ao Ministério da Educação e Cultura para trans- 
e municipais a serem criadas. A estratégia de Soeiro foi integrar o patrimônio ao processo de desenvolvimento em curso no país cooptando para isso outras esferas de poder como a estadual e municipal. A atuação da Dphan deveria ser complementada pelos Conselhos Estaduais de Cultura e pelos Serviços de Patrimônio Histórico e Artísticos estaduais estes, por sua vez, deveriam atender não só a proteção de obras e monumentos de interesse regional, como auxiliar a União na preservação dos monumentos nacionais ali localizados (ORMINDO, 2017).

A noção de patrimônio da humanidade, consolidada pela Unesco a partir dos anos 1960, justificou a formação de uma rede de cooperação cultural internacional, com objetivo de prestar assistência técnica ao Brasil por meio da elaboração de documentos e pareceres técnicos, envio de peritos, treinamento de pessoal, projetos promocionais de monumentos, museus e conjuntos arquitetônicos. O Nordeste, em especial a Bahia, foi uma das localidades estratégicas para atuação dessa rede de cooperação, focada em utilizar o turismo como fator de desenvolvimento sendo o patrimônio cultural, fundamental para atrair visitantes.

A consolidação da ação do governo Federal na Bahia na região formalizou-se através do Programa Integrado de Reconstrução das Cidades Históricas do Nordeste, que começou a ser elaborado em 1972 por membros dos ministérios da Educação e Cultura (Minc/lphan), da Indústria e Comércio, do Interior e do Planejamento, com o objetivo de preservar os monumentos tombados, tornando-os economicamente viáveis por meio de seu uso para fins turísticos (CORRÊA, 20I5) ${ }^{26}$. No que diz respeito aos governadores do Estado, pode-se dizer que tanto Luís Viana Filho, como Antônio Carlos Magalhães, filiados ao partido político ARENA foram escolhas conscientes dos militares ${ }^{27}$. Comprovando o alinhamento com as diretrizes do Governo Federal, o discurso proferido por Viana ao Presidente Médici, reitera a confiança na continuidade da obra dita revolucionária, garantindo-lhe que a administração do Estado faria todos os esforços para seguir os ideais do país (VIANA FILHO, I 984, p.79)

A criação do Museu do Recôncavo Wanderley Pinho esteve dentre as diversas ações do governo do Estado da Bahia no campo da cultura, incluindo o estabelecimento de leis relativas à preservação e gestão do patrimônio, algumas voltadas para o setor museológico.

\section{Industrialização, Petróleo e Turismo Cultural: o Patrimônio entre nu- ances políticas}

Antes de comentar a expografia e acervo do MWP merece menção aspectos econômicos que influenciaram a nova perspectiva sobre o Recôncavo baiano no que diz respeito à feição regional. São eles: a criação do Petróleo Brasileiro S/A, (PETROBRÁS) em 03 de outubro de $1953^{28}$, e o Centro Industrial de

formar a Diretoria do Patrimônio Histórico e Artístico Nacional (DPHAN) em Instituto do Patrimônio Histórico e Artístico Nacional (Decreto $n^{\circ}$ 66.967, de 27/7/1970).

26 A Portaria Miniplan 050/73, cria efetivamente o programa.VER Programa de Cidades Históricas (PCH). Disponível < http://portal.iphan.gov.br/dicionarioPatrimonioCultural/detalhes/33/programa-de-cidades-historicas-pch>.Acesso 09.08.2018

27 Antonio Lomanto Junior eleito governador via sufrágio um ano antes do golpe militar, em 1963, permaneceu no cargo até 1967, quando em 15 de março assumiu Luís Viana Filho, eleito de forma indireta pela Assembléia Legislativa. Após os quatro anos de seu mandato, a mesma Assembléia legislativa elegeu Antonio Carlos Magalhães para o cargo (1971-1974).

28 Os primeiros campos de petróleo no Brasil foram justamente o de Candeias (I94I), seguido de Aratu 
Aratu, colocando a Bahia numa posição diferenciada frente aos demais estados nordestinos. A gestão de Luís Vianna Filho como governador do Estado da Bahia entre os anos de 1967 e 1971 propôs políticas e ações voltadas para a região do Recôncavo, principalmente para o setor econômico. Recebeu do antecessor o Governador Lomanto Júnior, o projeto do Centro Industrial de Aratu $(\mathrm{ClA})^{29}$, empenhando-se em concretizá-lo. Ao assumir o governo da Bahia, a industrialização foi uma de suas prerrogativas, por acreditar o caminho mais curto para a recuperação econômica e o desenvolvimento social dotado de infraestrutura incluindo o "Centro de Saúde Magalhães Neto, o Conjunto Habitacional Rubem Vaz, o Museu Wanderley Pinho (instalado no antigo Engenho Freguesia) e o Centro Educacional Integrado de Aratu." (VIANA FILHO, I 984, p. I 5 e 29).

Frente ao intenso debate público que buscava compreender as causas do lento desenvolvimento no Nordeste, em especial da Bahia, Viana pregava condições favoráveis para a industrialização (energia do município de Paulo Afonso; gás natural de Aratu; petróleo do Recôncavo) necessitando apoio político do Governo Federal. Forma-se um novo ambiente socioeconômico e cultural brasileiro em que a educação passa a ser considerada estratégica para a formação de mão de obra e imprescindível ao processo de desenvolvimento. Quanto mais se consolidava o discurso da importância da industrialização do Estado da Bahia, mais acusada de principal vilã contra a preservação da memória histórica da qual a mesma Bahia seria guardiã. Dentro dessa nova perspectiva, o patrimônio foi definitivamente inserido na dinâmica socioeconômica do país. $O$ desafio do patrimônio não era mais a afirmação senão sua gestão frente às pressões urbanas e econômicas advindas com a modernidade (ORMINDO, 2017).A preservação do patrimônio foi compreendida como elemento fundamental para a identidade social, em particular a do Nordeste brasileiro, ligada a um esforço para o desenvolvimento que marcou a região a partir dos anos sessenta. Nas palavras do Presidente Médici, direcionada ao povo baiano em 1969, importava a participação do povo na nova dimensão do progresso e a Bahia sintetizava "todas as raças e de todos os credos", e também a "síntese entre a colônia quinhentista e a altivez emancipada que juntos estamos construindo; aqui, a síntese entre o Brasil que tem pressa e o Brasil que venera o seu passado." (VIANA FILHO, 1984, p.I I8).

Amparado pela Unesco e as Organizações dos Estados Americanos (OEA), o turismo cultural foi apresentado como a grande possibilidade de salvação para a economia dos países subdesenvolvidos, ao mesmo tempo, possibilidade de contribuir para a preservação dos Patrimônios nesses locais (ORMINDO, 2017). O Estado deveria facilitar na formação educacional de base, investindo em cursos técnicos, de graduação e pós-graduação que permitissem preparar os profissionais para as novas demandas do setor cultura ${ }^{30}$. $\mathrm{Na}$ medida em que as questões patrimoniais, a partir da década de sessenta, assumem cada vez mais a perspectiva mundial, tornando-se dever de todas as nações promoverem a

(1942), Itaparica (1942) e Dom João (1947), todos na Região Metropolitana de Salvador.

29 O projeto do Centro Industrial de Aratu (CIA), localizado a $17 \mathrm{~km}$ de Salvador, no eixo da BR-II6, previa a construção de complexo com área de $43.600 \mathrm{~m} 2$. A ideia era implantar uma área dotada de infraestrutura, destinada a atrair indústrias. Dentre as obras, o Porto de Aratu para escoamento da produção sem a necessidade de atravessar Salvador. Para implementar o projeto do CIA, o governador foi à Washington em busca de apoio do Banco Interamericano de Desenvolvimento (BID) (VIANA FILHO, 1984, p. I5).

30 A formação de profissionais capacitados a agir em prol das questões regionais demonstra-se através de experiências como o Curso Integrado sobre o Recôncavo, oferecido pelo Instituto de Estudos Brasileiros (IEB-USP) e pela Universidade Federal da Bahia no decorrer do ano letivo de 1969 em Salvador (IPHAN, 1969). 
salvaguarda, devemos considerar a importância que as resoluções da Unesco, voltadas para o tema, tiveram como parte do universo de possibilidades para a preservação, desenvolvimento e aproveitamento do patrimônio cultural brasileiro. O turismo, uma das principais vias de ação, com objetivos de permitir a promoção, o desenvolvimento e o sustento do patrimônio cultural (IPHAN, 2008, p. I 4) ${ }^{3 !}$.

A relação entre turismo, desenvolvimento econômico e a noção de $\mathrm{Pa}$ trimônio Mundial justificavam as ações e os Estados foram convocados para trabalhar em colaboração com o Dphan e com os técnicos internacionais. A missão do perito francês Michel Parent, realizada em duas etapas, percorreu 35 cidades brasileiras entre os anos de 1966 e 1967, teve como objetivo incluir o Brasil no Programa das Nações Unidas de Incentivo ao Turismo Cultural e, conseqüentemente, a adoção da preservação do patrimônio cultural no planejamento dos estados e municípios. O trabalho de Parent (publicado em março de 1968) impactou regionalmente alguns locais pela ênfase ao valor econômico dos bens culturais, "suscetíveis de constituir-se em instrumentos do progresso", pela necessidade de mobilizar esforços para melhor aproveitamento dos recursos monumentais de que se dispunha, como meio indireto de favorecer o desenvolvimento econômico do país. Isso significava dar destaque à promoção dos bens culturais e na "revalorização do patrimônio monumental em função do interesse público", ou seja, nas características e qualidades dos bens com vistas ao incentivo ao turismo (IPHAN, 2008, p.15).

Um dos capítulos do relatório versa exclusivamente sobre a Bahia, centrado na região de Salvador, uma prioridade, que seria a primeira cidade arte do Brasil para Michel Parent apontando a "necessidade imperiosa de salvar, no prazo mais curto - consideradas as ameaças - a primeira cidade arte do Brasil" em esforço para evitar o eminente desaparecimento dos remanescentes do passado (IPHAN, 2008, p.88). Cria-se então a Fundação do Patrimônio Artístico e Cultural da Bahia ${ }^{32}$, transformada na autarquia Instituto do Patrimônio Artístico e Cultural da Bahia (IPAC), por volta de 1972 (UCHÔA, 2006, p.7), responsável por salvaguardar o Patrimônio Artístico e Cultural do Estado.

As sugestões metodológicas e técnicas de Parent foram consideradas pelo Governador Luís Viana, que reorganizou os serviços turísticos da cidade do Salvador e direcionou as políticas a valorização desse setor no âmbito da

3I Em 1967 as Normas de Quito procuraram conciliar as exigências do progresso urbano com a salvaguarda de valores ambientais; a defesa e a valorização econômica do patrimônio um complemento ao planejamento urbano. As políticas deviam favorecer o turismo de acordo com a Recomendação de Paris (ORGANIZAÇÃO..., 1962, p.5). A Convenção para a Proteção do Patrimônio Mundial, Cultural e Natural ou Recomendação de Paris (1972), normatiza e estabelece parâmetros, diretrizes, conceitos essenciais do que devia ser definido como Patrimônio Mundial.A representação da UNESCO no Brasil formalmente criada em 1966 ocorreu na época em que a Organização dava seus primeiros passos em direção à descentralização. As relações de cooperação para questões relativas ao patrimônio foram maximizadas no período de 1967 a 1979, e se deu pelo fornecimento de assessoria e apoio técnico em geral fornecendo subsídios para a elaboração de políticas, estratégias nacionais, estudos de viabilidade, busca de financiamento e educação (UNESCO BRASIL, 1998, p. I4). Rodrigo Melo Franco de Andrade, então diretor do SPHAN-IPHAN empenhou-se na concretização desse projeto pela possibilidade de reverter benefícios para o campo patrimonial brasileiro e de propostas adotadas posteriormente, como de fato foram. (IPHAN, 2008, p. 14).

32 Lei Estadual $n^{\circ} 2.464$ de 13 de setembro de 1967. O programa da Fundação baseou-se a priori no conceito amplo de monumento, compreendendo a obra isolada como o ambiente urbano, cultural e paisagístico que o cerca. A recuperação e preservação dos monumentos implicaram em função e atividades que respeitassem as características do sítio a ser preservado. (IPAC, 1979). Ainda referente a proteção do patrimônio a mesma Lei n 2.464 (sessão terceira, artigo 36), cria o Conselho Estadual de Cultura do Estado da Bahia (CEC-BA), órgão colegiado consultivo e normativo com três Câmaras:Artes e Patrimônio Histórico, Ciências, e a de Letras e duas Comissões (de Legislação e Normas e Comissão de Organização da Revista de Cultura da Bahia)(VASQUEZ SOTO, 20I2). 
preservação e promoção do patrimônio: “ (...) um acervo de bens culturais invejável que não pertence, nesta altura, somente aos baianos ou aos brasileiros de maneira geral, mas, a toda a humanidade como deve ser." (IPAC, 1979, p. 9).A necessidade e relevância da preservação fundamentavam-se na centralidade da Região para o período colonial da História do Brasil, econômica e administrativamente, como primeira capital do Brasil. Em visita a Salvador em 22 de maio de 1970, o Presidente General Emilio Médici para demonstrar o apoio do Governo Federal às reivindicações da Bahia frente à instalação do pólo petroquímico do Nordeste, ressalta os encantos da Bahia e cultura associando-as ao Centro Industrial de $\mathrm{Aratu}^{33}$, relevante aos objetivos nacionais, com a promessa de recursos para a infraestrutura para atrair turistas (VIANA FILHO, 1 984, p. I 20). O "culto ao passado" torna-se, nesse contexto e contingência, o "elemento básico da formação da consciência nacional” (IPHAN, 1970, p. 2).

A região do Recôncavo, além dos bens tombados individualmente teve, na mesma época, o conjunto arquitetônico e paisagístico que compreendia as cidades de Cachoeira e São Félix reconhecidos como patrimônio mundial, por ser um dos maiores exemplares de arte e arquitetura barroca do Brasil, e o conjunto arquitetônico do Engenho Freguesia devidamente registrado.

\section{De Engenho a Museu: a concepção do Museu Rural}

Em 197I, decorridos quase trinta anos, a resposta sobre o futuro do Engenho Freguesia foi dada também com a nobre finalidade de continuar seu passado longo, transformando-se no Museu do Recôncavo que, por determinação do Governador Luis Viana FiIho, numa homenagem ao historiador, ao escritor, ao idealizador do museu do Engenho Freguesia, recebeu seu ilustre nome (ROCHA, 1973, p. 8).

Por mais que o campo da Museologia na Bahia ainda estivesse em processo de consolidação - vide que o curso de graduação seria aberto praticamente ao mesmo tempo em que se dá abertura do museu -, já havia o consenso de que o trabalho prático para a criação, concepção e montagem da exposição do Museu do Recôncavo Wanderley Pinho seria levado a cabo não apenas por museólogos, mas, também, por outros funcionários.

As fontes documentais consultadas durante a pesquisa nos levam a detalhar o edifício com suas características originais, e a exposição com algumas peças que estavam lá além de outras tantas terem sido retiradas de outros locais e contextos, para comporem aquele que viria a ser o acervo. Além disso, a forma como a exposição foi organizada revela muito sobre a visão do grupo que a concebeu, os profissionais envolvidos, todos eles, projetam seu próprio horizonte e expectativas, suas crenças e desejos.

O acervo do MWP foi composto com um grande número de objetos, das mais variadas origens, materiais e procedências, representando uma exposição essencialmente retrospectiva sobre diferentes temas que propunham a visão evolucionista da história, colocando o passado como uma etapa percorrida para chegar à essência do tempo presente.As coleções e a exposição do museu foram divididas em dois grupos. Um relacionado à história econômica, focalizando a produção da cana de açúcar, mas, também, tratando sobre a mandioca e o

33 MÉDICI, Emilio. Decreto de Posse. Brasília: Senado Federal - Casa Civil, 30 de outubro de 1969, p. 32-40. Disponível em http://www.biblioteca.presidencia.gov.br/presidencia/expresidentes/emilio-edici/discursos/1969/04.pdf/@@download/file/04.pdf. <22/06/20I8> 
fumo. O outro sobre a história social, política e religiosa do Recôncavo buscando tratar, de modo geral, da formação e desenvolvimento da sociedade regional. Tem-se o discurso diacrônico estabelecendo as coordenadas que definem a evolução relativa ao tema que aborda, no caso, a história do Recôncavo Baiano ${ }^{34}$.

Após a morte de Wanderley o primeiro passo foi adquirir o Engenho Freguesia junto à família para servir de sede para o Museu. A desapropriação, no campo jurídico, diz respeito à cessão ao domínio público, compulsória e mediante justa indenização de propriedade pertencente a um particular. $O$ fato de ser um bem tombado, patrimonializado a partir de legislação específica, torna-o especialmente apto a ser considerado de utilidade pública ${ }^{35}$. Em documentação obtida através da Diretoria de Museus (DIMUS/IPAC) ${ }^{36}$, a escritura definitiva de venda e compra, paga e Quitação, trata da alienação de propriedade agrícola denominada Engenho Freguesia, que foi objeto de desapropriação ou de inclusão em área reservada a utilidade pública ${ }^{37}$.

A autarquia estadual Centro Industrial de Aratu (CIA), representado pelo seu Superintendente dr. Rivaldo Gomes Guimarães foi quem efetivamente comprou o Engenho, com

\begin{abstract}
... casa de moradia, telheiro de antigo engenho, casas de trabalhadores e outras e antigas benfeitorias. Contendo a casa e a capela, que Ihe é anexa, diversos objetos, móveis que pela sua antiguidade, apresentam um valor histórico ademais do valor artístico. (...).(Primeiro Traslado de escritura definitiva de venda e compra, paga e quitação, 27 de outubro de (969) ${ }^{38}$
\end{abstract}

Por não ser originariamente construído como espaço expositivo o Engenho Freguesia surge do tecido cultural e social do lugar em que está inserido, ou seja, na área do Recôncavo daí decorrendo que o Museu não pertence aos grandes circuitos culturais urbanos e pode apresentar problemas que, de alguma maneira, restringem o acesso e sua visibilidade. Para a instalação foi impres-

34 Nessa perspectiva, segundo Maria Isabel Rocha Roque, a comunicação nos museus de história estabelece-se progressivamente como intramuseal - o museu processa uma discussão interna, reflexiva, confinada a equipe que organiza e elabora o discurso expositivo, sem entender as exigências e expectativas do público, nem ao menos trabalhar com a reação desse mesmo público para reformular sua mensagem. Em contrapartida cada visitante constrói o seu próprio discurso privado mantendo monólogos introspectivos e autônomos. Este modelo de comunicação seria viável nos casos onde há um predomínio do objeto exposto sobre o público fruidor. O valor patrimonial e documental atribuído ao objeto, como testemunho do passado, impõe-se como o pólo convergente de toda atividade museológica e como o principal elemento que determina o discurso expositivo (ROQUE, 2010, p. 58).

35 DECRETO-LEI N 3.365, DE 21 DE JUNHO DE 1941.

36 Recebidos gentilmente por Maria de Fátima dos Santos, Museóloga e Mestre em Museologia pela Universidade Federal da Bahia (20I5), na ocasião ocupava o cargo de Diretora de Museus (DIMUS) / Instituto do Patrimônio Artístico e Cultural da Bahia, autarquia vinculada a Secretaria de Cultura do Estado da Bahia.

37 A escritura do imóvel, datada de 27 de outubro de 1969, trata da venda por parte de Stela Calmon de Wanderley Pinho, inventariante do espólio de seu finado marido, Celina Gordilho de Araújo Pinho, Dr.Antonio Wanderley de Araújo Pinho e sua esposa Virginia Ottoni de Araújo Pinho. Todos representados por procuração pelo engenheiro Antonio Calmon Villas Boas (Luciano de Carvalho Marback Cartório Salvador, rua Padre Vieria, I I, Livro Numero 556, fls. 85v a 92)

38 O documento esclarece o valor da transação, que em comum acordo dos interessados fixou o preço da propriedade com tudo dentro - móveis e imaginária -, pelo valor total de $\$ 250.020,00$ Cruzeiros Novos. No arquivo do Museu de Arte da Bahia foi localizado o convênio entre a Secretaria de Educação e Cultura e o Centro Industrial de Aratu (CIA), para permitir o funcionamento do museu (datilografado, sem assinatura, sem espaços destinados a dados preenchidos, sem data de validade do convênio). 
cindível realizar obras no engenho sob a orientação do Iphan para adequar o espaço a sua nova função. A Casa Grande e Capela foram restauradas pela Superintendência do $\mathrm{CIA}^{39}$. Além da restauração parcial da totalidade do conjunto do telheiro, solar e capela, móveis foram restaurados como registra o catálogo do Museu, publicado em 1973 (ROCHA, 1973, p.8). A Petrobrás contribuiu na instalação tendo, inclusive, uma sala expositiva. Para Carlos Eduardo da Rocha, a participação da empresa seria importante pelo que representava para o desenvolvimento do país e da Bahia. Uma das modificações realizadas foi a construção da ponte de desembarque para facilitar o transporte de turistas e visitantes por via marítima, e aumentar a capacidade de transporte de passageiros por via rodoviária, providência tomada junto à Secretaria de Indústria e Comércio, em razão dos interesses para o desenvolvimento do turismo na região ${ }^{40}$.

O Museu foi uma das obras prioritárias do governador Luis Viana - a que nos referimos na epígrafe deste tópico -, que se empenhava em entregar o projeto funcionando antes do fim de seu mandato, que terminaria em I 5 de março de 197I. Foram remetidas para diversas instâncias do Governo, instruções do Chefe da Casa Civil para que se acelerasse a montagem e a inauguração pudesse ocorrer conforme o previsto. Para atender exclusivamente aos serviços de montagem a Secretaria do Trabalho e Bem Estar Social, colocou um automóvel à disposição da Divisão de Museus e Patrimônio Cultural ${ }^{4 !}$.

Carlos Eduardo da Rocha professor de História da Arte da Escola de Belas Artes da Universidade, poeta, crítico de arte, diretor do Museu do Estado, da Divisão de Museus e Patrimônio Cultural e, em conseqüência, responsável pela direção do MWP foi personagem influente no processo de criação. Pesquisador do Barroco, o que fazia com que Viana confiasse na sua expertise (BOAVENTURA, I99I, p.42), durante mais de um ano, realizou viagens ao Engenho Freguesia, algumas delas em companhia do governador Luiz Vianna, como parte das ações de planejamento e montagem do Museu. Outra pessoa muito próxima a Wanderley que colaborou diretamente para a concepção do Museu, participando do planejamento e montagem da exposição foi o historiador Pedro Calmon Muniz de Bittencourt, afilhado do imortal Miguel Calmon (ABREU, 1996), nascido na Bahia e com formação nas bases da intelectualidade da época. Houve preocupação na ocasião da concepção do Museu em valorizar o material museológico mais significativo da história econômica, social e política do Recôncavo (ROCHA, 1973).

No dia I 3 de fevereiro de 197I, uma manhã de sol, ocorreu efetivamente a inauguração com grande festa e presença de vários convidados. Constituiu-se em experiência nova manter em pleno funcionamento um museu instalado no campo, fato pouco comum. Em termos administrativos, o Museu nascia vinculado a Divisão de Museus e Patrimônio Cultural, da qual Carlos Eduardo da Rocha, como acima referido, era diretor.

A constituição do acervo do Museu do Recôncavo Wanderley Pinho foi complexa e se deu por meio da aquisição dos móveis do antigo Engenho Freguesia pelo Centro Industrial de Aratu, pela transferência de peças do Museu

39 Diretoria do Eng. Rivaldo Guimarães, pelo Departamento de Edificações de Obras Públicas do Estado da Bahia - DEP, na diretoria do Eng. Carlos Guimarães, sob a orientação técnica do Professor Jair Brandão do DPHAN (atual IPHAN)( SECRETARIA DE INDÚSTRIA E COMÉRCIO - IPAC-BA , 1978, p.32)

40 ROCHA, Carlos Eduardo da. Relatório das Atividades no exercício de 1971, 7 de Dezembro de 1971 p. 3; Arquivo MAB, Pasta: Dr. Carlos Eduardo da Rocha, Correspondências Emitidas, Anos 197I a 1973

4 I Oficio, 70/7I, 9 de fevereiro de 197I de Carlos para o Sr, Secretário do Trabalho em Bem Estar Social; Arquivo MAB, Pasta: Dr. Carlos Eduardo da Rocha, Correspondências Emitidas, Anos I97I a 1973. 
do Estado da Bahia (MAB), por empréstimos de instituições como o Instituto Geográfico e Histórico da Bahia e, também, através de doações de famílias tradicionais da elite baiana, a exemplo da do Barão de Cotegipe, os Calmon e o clã Araújo Pinho. Ainda que não tenhamos localizado um inventário completo do acervo do Museu com informações precisas sobre as procedências e modos de aquisição é possível, através das publicações e documentos, tecer perspectivas da exposição de longa duração que o inaugurou ${ }^{42}$. Mesmo incompleto, nos pareceu imprescindível trazer para a análise o panorama geral dos objetos, pois atuam de maneira contundente para conformar o espaço como museu, portanto, fundamentais para a composição do bem cultural em questão, justamente por revelar os aspectos intangíveis das práticas museológicas.

O acervo do Museu Wanderley Pinho, não obedece a uma tipologia específica, sendo constituído por: mobiliário, quadros, armas, tecidos, imagens sacras, instrumentos utilizados para desempenhar as mais variadas atividades, entre outros. Apesar de levar o nome de Wanderley Pinho, não era missão preservar e valorizar seus objetos pessoais, nem seu acervo particular. Por não ter habitado o local não foi objetivo tampouco reproduzir, sob a perspectiva biográfica, os espaços de vivência cotidiana.A expografia que ali se apresentava, na verdade, tentava abarcar um número grande de temas e assuntos referentes a uma possível história do Recôncavo, centrada nos grandes feitos e nos seus pretensos heróis, sujeitos pertencentes às principais famílias de elite da região, incluindo - aí sim -, a própria ascendência familiar direta de Wanderley Pinho.

$\mathrm{Na}$ concepção museológica adotada dentro da cronologia dos séculos $\mathrm{XVII}, \mathrm{XVIII}$ e XIX, as coleções foram montadas em salas com denominações de acordo com o material e às épocas evocadas: o Açúcar tem lugar de destaque, por ter sido durante séculos, o principal produto da economia colonial da região, o que acabou por influenciar diretamente na arquitetura do local. $O$ telheiro ou o Engenho propriamente dito o espaço escolhido para abrigar peças, objetos e instrumentos de trabalho agrícola relacionados ao processo de produção e transporte do açúcar (tachas de purgar e de cozimento, fornalha, formas de açúcar, caixas, prensas, moendas, arados, carros de boi, arreios, selaria, canoas, lanchas e saveiros). Destaca-se o guindaste primitivo do engenho (em madeira) que permitia o escoamento da produção (ROCHA, I 973, p. 4) Neste ambiente também ficou material relativo ao petróleo, a partir da participação da PETROBRÁS na descoberta e exploração dos primeiros campos petrolíferos do Brasil. $\mathrm{Na}$ tentativa de documentar a história econômica ressaltou-se, igualmente, a mandioca e o fumo pela importância regional, representativos da cultura indígena e das trocas culturais dos primeiros séculos de colonização. Foram expostas peças utilizadas na fabricação da farinha de mandioca, "a farinha de pau" e a prensa antiga de fumo.A participação dos negros na economia, através da exploração da mão de obra escrava, bem como sua contribuição para a formação social da região, a miscigenação e suas contribuições culturais com elementos materiais e "espirituais" foram representados, segundo Carlos Eduardo da Rocha, nas várias salas expositivas do Museu (ROCHA, 1973, p. II).

42 No ano anterior a inauguração do Museu, Carlos Eduardo da Rocha escreveu para a Revista de Cultura da Bahia, o artigo $O$ museu do Recôncavo Wanderley Pinho, onde era possível já dimensionar o projeto que daria corpo à instituição. No ano seguinte escolhido para organizar o catálogo do Museu publicado em duas edições (197I; revisada, em 1973), inicia referenciando a produção de Wanderley Pinho e sua importância para a história da Bahia. O Catálogo é um documento importante pela descrição e relato minucioso de todo o circuito expositivo, enriquecido com fotos e plantas baixas do edifício. Dividido em capítulos procura a perspectiva histórica, comenta as coleções e indica nomes de alguns doadores, descrevendo todos os pavimentos e peças de mais destaque. 
Destacamos a seguir aspectos do arranjo expositivo em visão panorâmica de modo a atestar a narrativa museográfica ali construída.

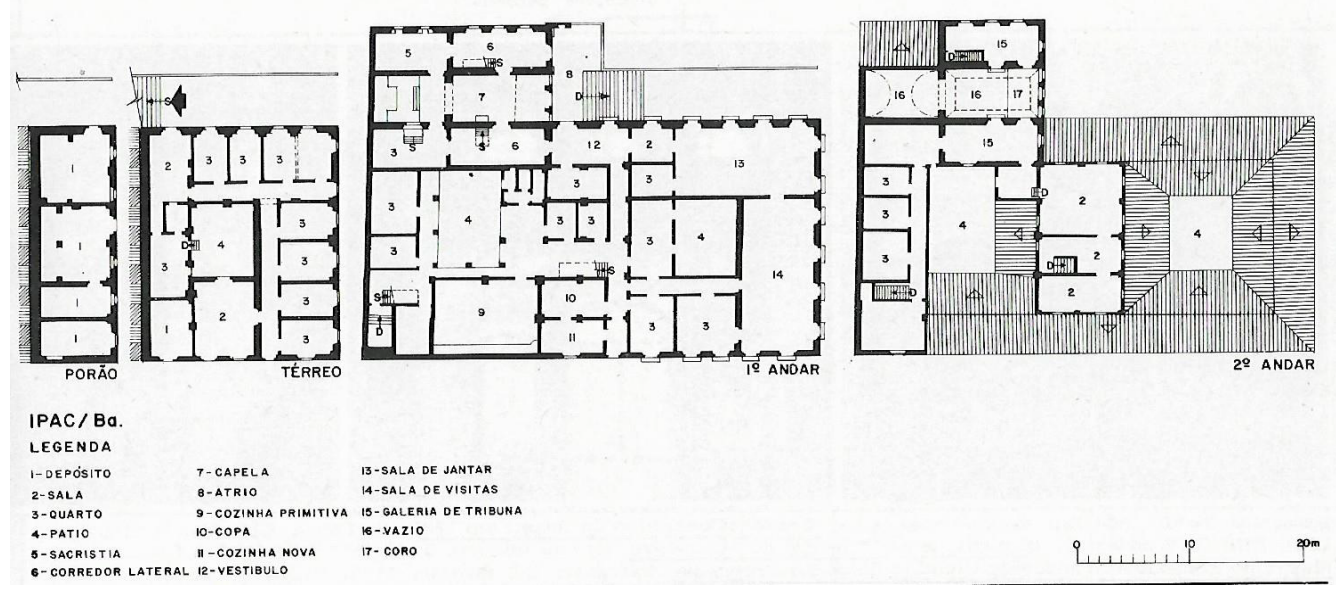

Planta baixa dos três pavimentos do Engenhos Freguesia. IPAC- INSTITUTO DO PATRIMONIO ARTISTICO E CULTURAL DA BAHIA, Inventário de Proteção do Acervo Cultural - Monumentos e Sítios do Recôncavo. SECRETARIA DE INDÚSTRIA E COMÉRCIO: Bahia, I978, v.ll, p.3।

No andar intermediário a Sala das Armas, apresentava pequena coleção de armaria, com destaque para armadura do século XVII em ferro, composta por três peças, peitoral, costaneira e gola, da coleção pertencente ao visconde de Itaparica, general Alexandre Gomes de Argolo Ferrão, herói da guerra do Paraguai. Na parede, dois floretes do século XVIII, e, nas prateleiras, aracabuzes e pistolas dos séculos XVII e XVIII (ROCHA, I973, p.I0). Completava a exposição da pequena sala, uma imagem de Nossa Senhora, pertencente ao próprio Engenho Freguesia e mencionada em inventário de 1818, cofres de ferro do século XVII, de formas rústicas, reforçados com lâminas cruzadas. Ainda no andar Intermediário, os atabaques antigos do rito Nagô, escavados em troncos, de feitura primitiva da coleção etnológica do Museu do Estado e uma escultura de Exu em madeira, do escultor Mário Cravo Júnior.

Nas duas últimas salas com intuito de mera documentação nas palavras de Carlos Eduardo da Rocha, os instrumentos de castigo aos quais eram submetidos os escravos (correntes com gargalheiras, algemas, troncos e ferramentas com fechaduras). Completando o programa desse piso, uma sala maior voltada para o pátio dedicada à participação do índio, no que se acreditava como as principais contribuições culturais para a formação da sociedade brasileira, caso da escultura popular de caráter monumental, em madeira pintada, a figura do Caboclo, utilizada pelo povo nos festejos da independência da Bahia e símbolo de nacionalismo, integrante das comemorações cívicas do Dois de Julho, além de arcos, flechas, sarabatanas, massas, tacapes de origem Tupi, oriundos da coleção organizada por Carlos Sales para o Museu do Estado (ROCHA, 1973, p. I2).

Eventos como a Guerra do Paraguai, a figura de Pedro II, a galeria de retratos de personalidades da Bahia durante o século XIX, objetos de uso pessoal e familiar do genro do Conde de Passé, o destaque para famílias notáveis do Recôncavo conviviam com o quarto de mucama, o quarto de banho antigo, ao lado de modernos quartos sanitários, a cozinha restaurada e espaço para exposições temporárias (inaugurada com exposição fotográfica da região do Recôncavo). Dos elementos aqui sucintamente comentados se infere o efetivo uso do passado compondo a cena museográfica desse que foi, provavelmente, o primeiro museu rural do Estado da Bahia. 


\section{Matizes em balanço}

Ao analisar as matizes políticas e tramas culturais na criação do Museu Wanderley Pinho, situado no Recôncavo Baiano, no período de 1968-I97I, imbricado à musealização do Engenho Freguesia procuramos, pautadas em diversas fontes documentais, recompor o percurso específico que transmutou o Engenho em Museu, evidenciando o detalhamento singular de uma prática patrimonial e, assim, dos envolvimentos e sentidos daquilo que pretendeu representar. O período político, o apoio e participação ativa do Estado, ou seja, do poder público e os agentes, ocupando posições socialmente importantes, anelou a rede de sociabilidade de uma elite em esforços para contornar obstáculos que porventura estivessem no caminho e, além disso, contar, em momento oportuno de novas perspectivas econômicas, com o apoio de empresas e companhias de porte que subsidiaram o restauro do Engenho Freguesia e a formação do acervo (além das doações privadas). Somos informados pelos documentos dos interesses em comum que não deixaram de evitar tensões, ao tempo em que, paralelamente, se fortalecia a legitimação e a valorização de um passado distintivo das elites rurais locais, reforçando a história cultural da Bahia para também e, ao mesmo tempo, a história da Bahia no Brasil, em um melindroso momento político (da ditadura) que bem soube articular os projetos culturais ao político, segundo os próprios interesses.

No caso da narrativa museográfica as decisões e seleções tomadas constatam a permanência em manter os feitos e glórias dando diretriz, igualmente por interesses, ao uso do passado, para dar visibilidade material ao que não deixa de ser tradição ideológica de um grupo, reunindo, através da figura de José Wanderley de Araújo Pinho, o museu rememorativo de uma camada particular da sociedade baiana. Para compô-lo conjugou-se ali, no antigo Engenho, em outro momento de sua trajetória, a política, a força da jurisdição e o capital simbólico em nome do Estado da Bahia. O MWP se tornaria integrado aos ideais correntes, incluindo, a ideia exploratória do turismo cultural (indicada pelo Relatório da missão financiada pela Unesco), como ferramenta para alcançar tal objetivo.

\section{Referências}

ABREU, Regina. A Fabricação do Imortal: Memória, História e Estratégias de consagração no Brasil. Rio de Janeiro: Rocco, 1996.

AZEVEDO, Esterzilda Berenstein de. Engenhos do Recôncavo Baiano - Brasília, DF: IPHAN/ Programa Monumenta, 2009. Disponível < http://portal.iphan.gov.br /uploads/publicaca o/ColRotPat7_EngenhosReco ncavoBaiano_m.pdf.>. Acesso II.01.2018

BAHIA. Secretaria da Cultura e Turismo; Fundação Cultural do Estado da Bahia. Inventário Sumário do acervo José Wanderley de Araújo Pinho. Salvador: A Fundação, 1998.

BOAVENTURA, Edivaldo Machado (org.). Homenagem a Luiz Viana Filho. Brasília: Centro

gráfico do Senado Federal, | 99|. Disponível <http://www2.senado.leg.br/bdsf/bi tstream/handle/id/91479/homenagem\%20a\%20Luiz\%20Viana\%20Filho.pdf.>.Acesso 09.03.2018.

CERÁVOLO, Suely Moraes. Inspetoria Estadual de Monumentos Nacionais. In 90

Anos do Museu Histórico Nacional em debate (1922-2012). (org.Aline Mon- 
tenegro Magalhães, Rafael Z. Bezerra), Rio de Janeiro, 20|4: I22-|56. Disponível < http://docvirt.com/docreader.net/DocReader.aspx?bib=mhn\&pagfis $=62110>$. Acesso 30.05 .2018

CHAGAS, Mario. A imaginação Museal: Museu, Memória e Poder em Gustavo Barroso, Gilberto Freyre e Darcy Ribeiro. Rio de Janeiro: MINC/IBRAM, 2009.

CHUVA, Márcia. Fundando a nação: a representação de um Brasil barroco, moderno e civilizado TOPOI, v. 4, n. 7, jul.-dez. 2003, pp. 3/3-333. Disponível <http://www. scielo.br/pdf/topoi/v4n7/2237-I0IX-topoi-4-07-003 I3.pdf.>.Acesso 30.05.20I8

CORRÊA, Sandra Rafaela Magalhães. O Programa de Cidades Históricas (PCH). In: REZENDE, Maria Beatriz; GRIECO, Bettina;TEIXEIRA, Luciano;THOMPSON,Analucia (Orgs). Dicionário IPHAN de Patrimônio Cultural. I. ed. Rio de Janeiro, Brasília: IPHAN/DAF/Copedoc, 2015.

CUNHA, João Fernandes. Genealogia vida e obra Wanderley Pinho. Revista do Instituto Geográfico e Histórico da Bahia.Vol. 19, I973, p. I -46.

DIAS, Maria da Graça Andrade. Memórias e Existências [manuscrito]: identidades e valores

na representação social do patrimônio no Recôncavo da Bahia. 2 v.Tese (Doutorado) -Universidade Federal de Minas Gerais, Escola de Arquitetura, 20I5. Disponível < http://www.bibliotecadigital.ufmg.br/dspace/handle//843/BUBD-A6QP6H>.Acesso 03.05 .2018

DÓCIO,Vanessa deAlmeida. Sob O Signo da Pedra e Cal:Trajetória da Política de Preservação do Patrimônio Histórico e Arquitetônico No Estado Da Bahia (I 927 1967). (dissertação) Programa de Pós- Graduação em História Social, Faculdade de Filosofia e Ciências Humanas, Universidade Federal da Bahia, Salvador/Bahia 20I4. Disponível < https://repositorio.ufba.br/ri/handle/ri/l 7625>.Acesso 09.03.20I8.

FONSECA, Maria Cecília Londres. O patrimônio em processo: trajetória da política federal de preservação no Brasil. Rio de Janeiro: UFRJ, IPHAN, 1997. GOMES, Eduardo. Engenho e Arquitetura. FUNDAJ. Ed Massangana, 2006.

IPAC (INSTITUTO DO PATRIMONIO ARTISTICO E CULTURAL DA BAHIA). Inventário de Proteção do Acervo Cultural - Monumentos e Sítios do Recôncavo. SECRETARIA DE INDÚSTRIA E COMÉRCIO: Bahia, I978, v.ll, p. 2932.

IPAC (INSTITUTO DO PATRIMONIO ARTISTICO E CULTURAL DA BAHIA). I 0 Anos de Fundação. Salvador : Secretaria da Educação e Cultura, 1979.

IPAC (INSTITUTO DO PATRIMONIO ARTISTICO E CULTURAL DA BAHIA). Anteprojeto para implantação do Parque Engenho Freguesia - Museu do Recôncavo:Wanderley Pinho. Salvador, Bahia, 20I I. Disponível < http://ftp. setur.ba.gov.br/prodetur/

documentosbahiabid/Amostra\%20Repreentativa/Museu\%20Wanderley\%20 Pinho\%20-

\%20Candeias/Anteprojeto\%20para\%20Implanta\%C3\%A7\%C3\%A3०\%20do\%20Parque

\%20do\%20Engenho\%20Freguesia.pdf.>.Acesso 06.06.2018.

IPAC (INSTITUTO DO PATRIMONIO ARTISTICO E CULTURAL DA BAHIA). Termo de referencia: Urbanização do Parque do Engenho Freguesia Museu do Recôncavo Wanderley Pinho e Projetos Complementares do conjunto de edificações. Salvador,Outubro de $201 \mathrm{I}$.

IPHAN (INSTITUTO DO PATRIMONIO HISTÒRICO NACIONAL). Compromisso de Brasília, abril de 1970. Disponível < http://portal.iphan.gov.br/uploads/ckfinde arquivos/Comprom isso\%20de\%20Brasi lia\%201970.pdf.>.Acesso II.02.20I8. IPHAN (INSTITUTO DO PATRIMONIO HISTÒRICO NACIONAL). As Mis- 
sões da Unesco no Brasil: Michel Parent. Rio de Janeiro: IPHAN, CODEDOC, 2008. Disponível < http://portal.iphan.gov.br/uploads/publicacao/SerPesDoc3 MichelParent_m.pdf $>$.Acesso 09.03.2018

MENESES, UlpianoT. Bezerra de. Memória e cultura material: Documentos pessoais no espaço Público. Revista Estudos Históricos. Rio de Janeiro: Ed. FGV.Vol. I I, n. 2I, p.89-I03, 1998. Disponível < http://bibliotecadigital.fgv.br/ojs/index.php/reh/article/view/2067 >.

MENESES, Ulpiano T. Bezerra de. O Campo do Patrimônio Cultural: uma revisão de premissas. Fórum Nacional Do Patrimônio Cultural, I. Anais... Ouro Preto, v. I, 2009. Disponível em http://portal.iphan.gov.br/portal /baixaFcdAnexo.do?id=1653.> Acesso 02/02/ 2018

NASCIMENTO,Anna Amélia Vieira. Wanderley Pinho Historiador. Revista do Instituto Geográfico e Histórico da Bahia.Volume 87, 1987, p.227-238.

ORMINDO, Paulo. Patrimônio Cultural e Natural como fator de desenvolvimento: a revolução silenciosa de Renato Soeiro, 1967-1979. Revista do Instituto do Patrimônio Histórico e Artístico Nacional, N³5, 2017, p. 45-64. Disponível < http://portal.iphan.gov.br/uploads/publicacao/revpat_35.pdf>.Acesso 06.06.20I8. ORTIZ, Renato. A Moderna tradição Brasileira. 3 ed. São Paulo, SP: Brasiliense, I99|.

PEREIRO, Xerardo. Património cultural: O casamento entre Património e Cultura. ADRA.- Revista dos sócios do Museu do Povo Galego, Santiago de Compostela, n. I, p. 23-4I, 2006. Disponível < https://formacaompr.files.wordpress. com/2010/03/patrimonio-cultural_xerardo-p.pdf>. Acesso em 3I.I0.20I4 PIRES, Fernando Tasso Fragoso. Antigos Engenhos de açúcar no Brasil. introdução, história dos engenhos e legendas. Rio de Janeiro: Nova Fronteira, 1994.

REDE, Marcelo. História a partir das coisas: tendências recentes nos estudos de cultura material. Anais do Museu Paulista: São Paulo, v 4, nI, 1996. Disponível < http://www.revistas.usp.br/anaismp/article/view/5343/6873.>.Acesso 19.05.20I8. ROCHA, Carlos Eduardo da. Museu do Recôncavo Wanderley Pinho: O Engenho da Freguesia. Salvador : Editora Itapuã, 1973 (2ªd).

RODRIGUES, Fabíola. A Patrimonialização do Cotidiano: Desafio para as Políticas Públicas. Revista Rua, Campinas, n. 18, v.2, nov.2012. Disponível < https://www.l abeurb .unicamp. br/rua/na teriores/pages/pdf/I8-2/8-I8-2.pdf >.Acesso 19.05.20I8. ROQUE, Maria Isabel Rocha. Comunicação no Museu. In BENCHERIT, Sara F; BEZERRA, R.Zamorano, MAGALHÃES,Aline M. (org). Museus e Comunicação: exposição como objeto de estudo. Rio de Janeiro: Museu Histórico Nacional, 20 I 0:4768.

SANTOS, Maria de Fátima dos.As Instâncias da Gestão de Museus vinculadas ao Governo da Bahia: uma análise das políticas e das ações socioculturais e educativas de 1967-2013. (Dissertação). PPG Museu, FFCH, Universidade Federal da Bahia, 2016. Disponível < https://repositorio.ufba.br/ri/handle/ri/l9002>.Acesso 03.06.20I8 SPHAN - SERVIÇO DO PATRIMONIO HISTÓRICO A ARTISTICO NACIONAL. PROCESSO DE TOMBAMENTO 322 T-1943, p.2 e 4: Engenho Freguesia. Acervo Digital IPHAN. Disponível < http://acervodigital.iphan.gov.br/xmlui/discover>.Acesso 12.05.20I8

TELLES, Marcio Ferreira. Entre a Lei e As Salsichas: Análise dos Antecedentes do Decreto-Lei 25/37.V ENECULT - Encontro de Estudos Multidisciplinares em Cultura, 2009. Disponível <http://www.cult.ufba.br/enecult2009//9408.pdf.> Acesso 03.06.2018

UCHÔA, Sara. Políticas Culturais na Bahia (1964-1987). Salvador, 2006. Disponível < http://www.cult.ufba.br/arquivos/politica s_culturais_1964_1987_.pdf.> Acesso 
2/0I/20I8.

VASQUEZ SOTO. Trajetória Histórica do Conselho Estadual de Cultura e as Políticas Culturais Na Bahia. Dissertação (mestrado) -, Instituto de Humanidades, Artes e Ciências Professor Milton Santos Universidade Federal da Bahia, Salvador, 2012. Disponível < https://repositorio.ufba.br/ri/handle/ri//495 I>. Acesso 03.06.2018

VIANA FILHO, Luiz. Petróleo e Industrialização da Bahia 1967-I97I. Senado Federal: Brasília, Centro Gráfico, 1984.

VIANA FILHO, Luiz. Centenário de Wanderley Pinho. Bahia, 1990. Disponível $<$

https://www2.senado.leg.br/bdsf/bitstream/handle/id/94268/centenario\%20de\%20 wanderley\%2

Opinho.pdf?sequence=5.>.Acesso 26-08-20I7 